\title{
Patrycja Rosół*
}

iD https://orcid.org/0000-0002-8421-3729

\section{Konteksty muzyczne w Rymach dziecięcych Kazimiery Iłłakowiczówny}

Rymy dziecięce $e^{1}$ Kazimiery Iłłakowiczówny to tomik wierszy, którego powstawanie i wydanie datuje się na lata 1922-1923. To zbiór składający się z czterdziestu dziewięciu miniatur poetyckich skierowanych do dzieci. W twórczości Kazimiery Iłłakowiczówny nie są to jedyne utwory o tematyce dziecięcej. Napisała ona również tomiki, takie jak: Czarodziejskie zwierciadełka. 50 wróżb wierszem, Wesołe wierszyki oraz ich poszerzone wersje Wiersze dziecięce i Zwierzaki i zioła, jednak jako pierwsze w obrębie tej tematyki powstały Rymy dziecięce. Kazimiera Iłłakowiczówna napisała również powieść dla dzieci pod tytułem Bajeczna opowieść o królewiczu La-Fi-Czaniu, o żołnierzu Soju i o dziewczynce Kio. Iłłakowiczówna przygotowała swoje pierwsze wiersze dla dzieci z uwagi na dwie siostrzenice, dla których pragnęła stworzyć historie pełne dziecięcych przeżyć. W wywiadzie dla „Wiadomości Literackich” artystka wspomniała, że:

wewnętrzną pobudką była chęć napisania książki, jaką mogłoby napisać dziecko, a jaką ma prawo napisać poeta. Przecież świat drobnych rzeczy i przeżyć może mieć dla poety takie samo znaczenie jak dla dziecka ${ }^{2}$.

Zbiór wierszy Iłłakowiczówny to ukazanie świata z perspektywy dziecka, zainteresowanego otaczającą go rzeczywistością. Głównymi postaciami oprowadzającymi po najbliższych miejscach, czyli mieszkaniu, sypialni, podwórku, pasiece, są

* Mgr, Uniwersytet Śląski, Wydział Filologiczny, Instytut Nauk o Literaturze Polskiej im. Ireneusza Opackiego, pl. Sejmu Śląskiego 1, 40-032 Katowice; e-mail: patrycja.rosol@student.uni.opole.pl

1 K. Iłłakowiczówna, Rymy dziecięce, Wydawnictwo Poznańskie, Poznań 1972. Cytaty z wierszy podaję za tym wydaniem.

2 S. Podhorska-Okołów, Z tajników poetyckiego rzemiosła. J.K. Iłłakowicz o swojej twórczości, „Wiadomości Literackie” 1925, nr 9, s. 2. 
Krzysia i Lalka. Iłłakowiczówna w bardzo zabawny, wręcz komiczny sposób przedstawia przeróżne sytuacje z życia dziecka. Bohaterki opowiadają m.in. o zwierzętach w utworach: Prosię, Gil i sroka, Myszy, Kot, o owadach - w wierszu Trzmiel $i \dot{z} u k$, oraz wymyślają zabawne przygody np. Ślub Królewny. Mówią one o różnych, na wpół zmyślonych na wpół realnych sytuacjach, jakie w ich życiu mogły się wydarzyć, m.in. o spotkaniu bosej kaczuszki (Kołysanka lalki), o nastaniu wiosny (Wiosna), czy o rozmowie z krową (Wizyta u krowy). Krzysia śpiewa kołysanki (Kołysanka Krzysi), kłóci się ze szpakiem (Nikczemny szpak), a także z oszukującym w sklepie sprzedawcą (Zły lejba). Służy nawet dziecięcą radą: Jak się najlepiej opędzać od szerszenia. Do wybranych przez siebie utworów z tomiku poetki Karol Szymanowski skomponował cykl pieśni pt. Rymy dziecięce op. 49 na głos i fortepian. Wydawać się może, że jego zainteresowanie wierszami Iłłakowiczówny nie było przypadkowe, choć nie wynikało jedynie z ich walorów artystyczno-literackich. Kompozytor miał dwie siostrzenice - młodszą Krysię oraz starszą Alusię. Zbieżność imienia głównej bohaterki Rymów dziecięcych - Krzysi, z imieniem młodszej siostrzenicy Szymanowskiego, mogła zaważyć na decyzji napisania muzyki akurat do tych miniatur. W krótkim czasie niespodziewanie zmarła starsza siostrzenica, Alusia, dlatego cykl pieśni został opatrzony dedykacją „Pamięci Alusi”, z której to tragiczną śmiercią bardzo ciężko było pogodzić się Szymanowskiemu.

Całą twórczość kompozytora można podzielić na trzy główne okresy. Pierwszy z nich, neoromantyczny, określany także jako młodopolski. Drugi nazywany jest okresem impresjonistycznym, natomiast ostatni, w którym słychać zainteresowanie rodzimą muzyką ludową, to okres narodowy. Rymy dziecięce zaliczają się do wspomnianego trzeciego okresu twórczości Karola Szymanowskiego. Był to czas kiedy powstały również Słopiewnie op. 46 do słów Juliana Tuwima, Trzy kołysanki op. 48 do słów Jarosława Iwaszkiewicza, a także Siedem pieśni do słów Jamesa Joyce’a op. 54. Szymanowski nie zapytał Kazimiery Iłłakowiczówny o pozwolenie komponowania do jej wierszy muzyki. Swoje gotowe pieśni wysłał od razu do wydawnictwa Universal-Edition, w którym zostały one przetłumaczone na języki obce i w krótkim czasie wydane. Między twórcami zrodził się artystyczny spór. Autorka wierszy, jak opisuje ją Jerzy Kwiatkowski: „była zresztą w ogóle poetką chadzającą własnymi drogami, niepodatną na współzależności...”’3. Toteż aroganckie zachowanie Szymanowskiego uraziło artystkę. O całej sytuacji opowiada ona w Portretach Godzin Łucji Danielewskiej:

A co do Szymanowskiego, to wokół naszej znajomości narosła legenda. Otóż on do moich Rymów dziecięcych skomponował dwadzieścia pieśni. Rozgniewałam się

3 J. Kwiatkowski, Dwudziestolecie międzywojenne, Wydawnictwo Naukowe PWN, Warszawa 2002, s. 80. 
bardzo, że nie zapytał mnie o zgodę. Nie wiem, przez kogo dotarła do niego wiadomość o moim gniewie. Może przez Zofię i Karola Stryjeńskich? Dość, że doszło do mego osobistego spotkania z Karolem Szymanowskim, a był to piękny, elegancki i dobrze ułożony mężczyzna. Oczywiście zamiast jakiejś strasznej awantury, doszło do porozumienia. „Umówiliśmy się”, że Szymanowski zapłaci mi bodaj 400 złotych, czy też użyje innego środka płatniczego, a ja za to na całe życie udzielę mu zezwolenia na komponowanie do mojej poezji ${ }^{4}$.

Ta pamiętna sytuacja została również opisana przez Jarosława Iwaszkiewicza w jego książce Spotkania z Szymanowskim:

Pamięci Alusi (zrazu dedykacja zawierała proste słowa: „Kochanej siostrzenicy Alusi Bartoszewiczównie”) poświęcone są jedne z najpiękniejszych pieśni Szymanowskiego, Rymy dziecięce do słów Iłłakowiczówny. Poetka ta dowiedziawszy się, że Szymanowski skomponował muzykę do jej wierszy nie pytając o jej pozwolenie, obraziła się bardzo i przysłała Szymanowskiemu dość niegrzeczny list. Szymanowski oburzył się na Iłłakowiczównę - chciał pieśni zniszczyć, ale już poszły do Universal-Edition, która miała je szybko wydać, licząc na popularność i dostępność tych dziecinnych melodii. Trzeba było coś na ten spór artystyczny zaradzić. Dzięki wstawiennictwu przyjaciół Iłłakowiczówna pogodziła się z Szymanowskim, wyrażając ex post zgodę na skomponowanie pieśni, a widomym znakiem owej zgody było zebranie u Szymanowskiego, na którym była obecna poetka Rymów dziecięcych, wydawca tej pięknej książki Karol Stryjeński, ja z moją żoną i inni. Na tym zebraniu Stasia odśpiewała przy akompaniamencie autora owe wzruszające i zabawne, miłe i piękne pieśni. Surowa poetka udobruchała się zupełnie. Niemniej przeto od owej pory na odwrotnej stronie karty tytułowej jej książek zjawiła się adnotacja: Prawo przedruku, tłumaczenia $i$ komponowania do tych słów muzyki zastrzeżone przez autorkę ${ }^{5}$.

Te dwie relacje są do siebie bardzo zbliżone, a samo wspomnienie o zaistniałej sytuacji, zarówno u Łucji Danielewskiej jak i Jarosława Iwaszkiewicza, może świadczyć o tym, że spór między artystami, dziś nieco zabawny, był jednak trudny do rozstrzygnięcia.

By zażegnać konflikt prawykonanie Rymów dziecięcych op. 49 odbyło się prywatnie w obecności Kazimiery Iłłakowiczówny, a sam twórca akompaniował swojej siostrze, śpiewaczce - Stanisławie Korwin-Piotrowskiej. Poetka przyznała, że w wykonaniu nie potrafiła usłyszeć swoich tekstów w całości i jak stwierdziła

4 Ł. Danielewska, Portrety Godzin. O Kazimierze Iłłakowiczównie, Wydawnictwo Czytelnik, Warszawa 1987, s. 193.

5 J. Iwaszkiewicz, Spotkania z Szymanowskim, Polskie Wydawnictwo Muzyczne, Kraków 1981, s. 73. 
słyszała tylko same samogłoski ${ }^{6}$. Po wykonaniu utworów w filharmonii cykl $R y$ mów dziecięcych zyskał przychylność słuchaczy.

Pozornie proste teksty zostały opatrzone linią melodyczną i ilustracyjną partią fortepianu, mocno działającą na wyobraźnię odbiorcy. Warto zauważyć, w jaki sposób kompozytor wykorzystał środki muzyczne do wyobrażenia różnych zdarzeń przedstawionych w wierszach. Teresa Chylińska wyróżnia Szymanowskiego na tle innych kompozytorów minionych epok:

Wielcy poprzednicy [Szymanowskiego]: Schumann w Scenach dziecięcych, Musorgski w Izbie dziecięcej czy Debussy w Gwiazdce dzieci bezdomnych i Kąciku dziecięcym opisują świat dziecka z perspektywy człowieka dorosłego. Szymanowski bezbłędnie pojął artystyczny zamiar Iłłakowiczówny i postąpił inaczej: zasiadł w dziecinnym pokoju, zostawił na boku swoją „dorosłość” i spróbował popatrzeć na świat oczami dziecka?

Aranżacja muzyczna pozwala wczuć się w sytuację oraz klimat wiersza, oddać emocje i wgłębić w przeżycia głównych bohaterek. W melodyce odzwierciedlona jest różnorodność nastrojów i sytuacji obrazujących świat dziecięcych przeżyć ${ }^{8}$. Można usłyszeć charakterystyczne motywy muzyczne oddające cechy podmiotu lirycznego. Dodatkowo walory brzmieniowe zawarte w wierszach Iłłakowiczówny sprzyjały pomyślnemu przekładowi intersemiotycznemu.

By zobaczyć, w jaki sposób Szymanowski zilustrował muzycznie wybrane teksty, podzieliłam je na dwie grupy: kołysanki oraz utwory humorystyczne. Pierwsza $\mathrm{z}$ nich to analiza utworów związanych z zasypianiem pt. Przed zaśnięciem, Kołysanka gniadego konia i Kołysanka Krzysi. Druga natomiast charakteryzuje się wesołymi miniaturami, o czym świadczą nawet same tytuły: Prosię, Jak się najlepiej opędzać od szerszenia oraz Trzmiel i żuk.

Pierwsza miniatura poetycka, otwierająca zbiór pieśni Karola Szymanowskiego, nosi tytuł Przed zaśnięciem. W jej klimat wprowadza delikatna i subtelna tonacja A-dur oraz łagodny, jednostajny, kołyszący, miarowy rytm. Powtarzające się motywy rytmiczno-melodyczne wprowadzają w nastrój wyciszenia i spokoju. Dopiero w szóstym takcie kołysanki pojawia się charakterystyczny długi tryl. Przypada on na słowo „kolorowych”, gdzie mowa o wielobarwnych myślach prze-

6 K. Iłłakowiczówna, O muzyce i Szymanowskim, w: Wspomnienia i reportaże, oprac. i posł. opatrzyli J. Biesiada i A. Włoszczyńska, Biblioteka „Więzi”, Warszawa 1997, s. 182.

7 T. Chylińska, Wprowadzenie, w: Mieczysław Karłowicz: Pieśni, Karol Szymanowski: Rymy dziecięce op. 49, E. Szmytka - sopran, L. Kende - fortepian, [CD, nagrania dokonano w studiu Radia Kraków 28 i 29 kwietnia 2013 r.]

8 E. Dziębowska, Karol Szymanowski w: Encyklopedia muzyczna PWM, Część biograficzna, t. 10, Polskie Wydawnictwo Muzyczne, Kraków 2007. 
latujących przez głowę zasypiającego dziecka. Napięcie, które nie pozwala zasnąć, a dodatkowo muzyczne pokazanie nerwowości w postaci nieustannego, drżącego trylu pojawiającego się już do końca utworu, obrazuje i natarczywie przypomina o niespokojnych myślach towarzyszących zasypianiu. W swojej wersji Karol Szymanowski wprowadza klamrę kompozycyjną. Utwór nie kończy tak samo jak zakończyła go Iłłakowiczówna. Kompozytor dodaje ostatni wers imitujący początkowe cztery takty, z powtórzeniem słów: „jakby się dobrze spało”. Jest to klamra, a zarazem westchnienie niosące za sobą niepokój z powodu myśli, które nie pozwalają spokojnie zasnąć przed snem.

W wierszu Kołysanka gniadego konia, pragnę zwrócić uwagę na powtarzalność litery „o” w całym jego przebiegu. Może się wydawać, że Karol Szymanowski podczas lektury odkrył tę cechę muzyczną w tekście i postanowił w szczególny sposób się nią posłużyć. To właśnie na samogłoskach wprowadził dłuższe wartości rytmiczne, przez co uzyskał efekt spokoju i wyciszenia, który idealnie pasuje do charakteru kołysanki. Analizując kumulację tej samogłoski można dojść do wniosku, że ciemne „o" - rozwlekłe i melancholijne - odpowiednio nadaje się do tego, by to na nim rozciągnąć muzyczną frazę. Dzięki temu kompozytor podkreślił kołysankowy charakter utworu. Dariusz Pawelec zauważa, że skupiona litera „o" pozostaje w zupełnej zgodzie z takimi wyrazami jak „noc" i „kołysanka”. Zatem wyjątkowy nadmiar akurat tej głoski miałby swoje uzasadnienie w kołysance Iłłakowiczówny. Głoska „o” wybija się na pierwszy plan i dominuje pośród innych dźwięków. Roman Jakobson określiłby to mianem "leitmotivu wokalicznego"10. Biorąc pod uwagę warstwę muzyczną kolejnego utworu - Kołysanka Krzysi, warto przyjrzeć się bliżej akompaniamentowi. Rozpoczyna się on na początku spokojnymi miarowym dwugłosem, bardzo cichym, w którym słychać pojawiające się dźwięki chromatyczne. Podczas gdy rozpoczyna się fragment opowieści o listeczku, Szymanowski dodaje jeszcze jeden głos. Odróżnia się on od pozostałych rytmem punktowanym. Akompaniament zostaje przez ten zabieg znacznie urozmaicony. Swój szczytowy moment osiąga w ostatnim dwuwersie. Towarzyszenie fortepianu to już czterogłos, a całe napięcie kumuluje się na słowie „anieli”, którzy to zabierają do nieba spadający z drzewa listeczek. Najwyższe dźwięki sopranu, wyśpiewane poco sostenuto, a więc trochę powściągliwie, wstrzymując dźwięki i zarazem ociągając tempo powodują, że cała akcja skupia się na zakończeniu tego utworu. Karol Szymanowski ponownie dodaje w swojej interpretacji wiersza klamrę kompozycyjną, na którą składa się pierwszy wers o podobnej harmonii i kołyszącym rytmie.

9 D. Pawelec, Od kołyski do trenu. Z hermeneutyki form poetyckich. Wydawnictwo Uniwersytetu Śląskiego, Katowice 2006, s. 40.

10 R. Jakobson, Poetyka w świetle językoznawstwa, w: tegoż, W poszukiwaniu istoty języka. Wybór pism. Wybór, red. nauk. i wstęp M.R. Mayenowa, t. 2, Państwowy Instytut Wydawniczy, Warszawa 1989, s. 113. 
Teresa Chylińska opisała akompaniament tej kołysanki w taki sposób: „Fortepian naśladuje chwiejny ruch drewnianej kolebki, a gdy trzeba - maluje porywy wiatru, szarpiącego listeczkiem"'1.

$\mathrm{W}$ drugiej grupie znajdują się wiersze o charakterze pełnym dowcipu, groteski i humoru. W utworze Prosię pierwszy wers, na który składa się tytułowe słowo, zostało $\mathrm{w}$ muzyce podkreślone tenuto $\mathrm{w}$ linii melodycznej oraz partii akompaniamentu. Marszowy rytm przywodzi na myśl spacerujące, a wręcz paradujące po łące, prosię. („Prosię poszło spacerować po wieczornej rosie”). Kompozytor dodatkowo zaznacza wartość słów crescendem oraz opadającą stopniowo melodią, a także drobniejszymi wartościami rytmicznymi. Ciekawym zabiegiem jest zastosowanie lekko i tanecznie brzmiącej trioli, mającej obrazować ukłon, gdyż pojawia się ona dokładnie na słowach: „mu się ukłonił”. Użycie ritenuto przez kompozytora sugeruje słuchaczowi zbliżanie się do sedna wiersza. W ostatnim wersie utworu kompozytor zaznacza wykrzyknienie „precz”, poprzez chwilową rezygnację $\mathrm{z}$ akompaniamentu. Partia fortepianu efektownie powraca w momencie, gdy śpiewaczka ma za zadanie swoim głosem naśladować szczekanie psa. Ujadanie Burka wyrażone jest za pomocą opadającej gamy chromatycznej z zastosowaniem w dwugłosie akompaniamentu dźwięków odległych od siebie o tryton, który swoim dysonującym brzmieniem dodatkowo podkreśla niesympatyczne przepędzenie.

W nieco dramatycznym utworze Jak się najlepiej opędzać od szerszenia charakterystyczna staje się drobna figura szesnastkowa naśladująca lot szerszenia. Szybkie tempo naprowadza nasze myśli na skojarzenie z ruchliwością owada. $\mathrm{W}$ jednym z taktów kompozytor nad nutami obrazującymi słowa „płaszczyk jej poszarpał, pokłuł”, zaznaczył akcenty oddające muzycznie wrażenie dźgania. Dźwięki te są mocno osadzone, wykonane z odrywaną, szybką artykulacją, dobrze naśladującą kłucie. Konanie w wersie „bez ciebie samotnie kona” przedstawione zostaje za pomocą zdecydowanego crescenda potęgującego dramatyczny nastrój przy jednoczesnym rallentando, spowalniającym rytm i nasuwającym skojarzenie zanikania życia.

Interesujący wydaje się także utwór Trzmiel i żuk. To miniatura, w której kompozytor zastosował budowę trzyczęściową typu repryzowego $\mathrm{z}$ odmienną $\mathrm{w}$ środku częścią b. W jego skrajnych fragmentach występują mocne akcenty i ostra artykulacja, jednak część środkowa to wyraźne wprowadzenie kontrastującego, spokojnego tempa do dzieła. W ten sposób zestawione zostały dwie główne tytułowe postaci trzmiela i żuka. Tak jak w poprzednich pieśniach - Prosię i Jak się najlepiej opędzać od szerszenia - kompozy tor podporządkował kształt melodii scharakteryzowaniu zwierząt. Już od pierwszego taktu możemy zauważyć podobieństwo nieustającego trylu do brzęczenia trzmiela. Specyficzne trylowanie ustaje, gdy 
w tekście pojawia się żuk. Początkowe tempo - vivace agitato - sugeruje wykonanie tej części utworu prędko, z pobudzeniem. Natomiast druga część (b) znacznie zwalnia akcję, a akompaniament zdaje się być ociężały. Głównym czynnikiem zastosowania budowy repryzowej, mógł być fakt podkreślenia i zwrócenia uwagi na postać żuka. Żuk kojarzy się z dużym owadem, żyjącym bez pośpiechu. Mimo że słowo „żuk” zawiera trzy litery, mamy wrażenie, iż samogłoska „u” znacznie wydłuża cały wyraz. Owady te różnią się od siebie zatem nie tylko ze względu na ich usposobienie przez naturę, ale także z perspektywy analizy głosek w wyrazie. Kompozytor również podkreślił tę opozycję i nie zawahał się użyć licznych środków potęgujących to wrażenie, m.in. za pomocą nieprzerywanego trylu, akcentów, czy zróżnicowania tempa.

Miłość do siostrzenic, zarówno ze strony Iłłakowiczówny, jak i Szymanowskiego, zaowocowała powstaniem tak wyjątkowych utworów. Nie chcieli oni, aby bariera wiekowa była przeszkodą w przejściu do świata dzieci. Dzięki swym talentom artyści pragnęli przeniknąć w sposób myślenia i postrzegania rzeczywistości przez najmłodszych. Niewątpliwie wyjątkowa muzyczna wrażliwość kompozytora wprowadza nas $\mathrm{w}$ świat widziany oczyma dziecka. Wiersze Iłłakowiczówny zostały znakomicie uwydatnione. To nastrój i charakter tekstu nadany przez poetkę dyktuje jego muzyczny obraz. Adresat tych utworów, bez względu na wiek, może czerpać radość zarówno z odbioru literatury, jak i muzyki. W muzycznym przekładzie wierszy, dokonanym przez Karola Szymanowskiego, wyraźnie słychać kompozytorski zamysł ilustrowania tekstu dźwiękami. Celowe zabiegi dynamiczne, rytmiczne, agogiczne oraz melodyczne doskonale wpisują się w tekst i odwzorowują charakter czy to kołysankowych, czy to zabawnych treści utworów Kazimiery Iłłakowiczówny. To różnorodne oraz interesujące połączenie ze sobą poezji z muzyką zyskało uznanie wśród słuchaczy. Jak pisała Stanisława Szymanowska po wykonaniu pieśni we Lwowie 11 grudnia 1923 roku:

Niedawno odnieśliśmy z Karolem niesłychany sukces we Lwowie koncertem złożonym w całości z jego pieśni. Istny rekord - bilety rozkupiono szturmem w cztery godziny! Od dziesiątej rano do pierwszej po południu cała sala została wyprzedana, tłum ogromny. Rymy dziecięce miały olbrzymie powodzenie, publiczność śmiała się i płakała, bisowaliśmy wszystkie ${ }^{12}$.

Ta popularność może świadczyć o tym, że Rymy dziecięce z całą pewnością zasługują na miano jednych z najoryginalniejszych dzieł liryki wokalnej XX wieku. 


\title{
Bibliografia
}

Danielewska Łucja, Portrety Godzin. O Kazimierze Iłłakowiczównie, Wydawnictwo Czytelnik, Warszawa 1987.

Dziębowska Elżbieta, Karol Szymanowski, w: Encyklopedia muzyczna PWM, Część biograficzna, t. 10, Polskie Wydawnictwo Muzyczne, Kraków 2007.

Iłłakowiczówna Kazimiera, O muzyce i Szymanowskim, w: Kazimiera Iłłakowiczówna, Wspomnienia i reportaże, oprac. i posł. opatrzyli Jacek Biesiada i Aleksandra Włoszczyńska, Biblioteka „Więzi”, Warszawa 1997, s. 182.

Iłłakowiczówna Kazimiera, Rymy dziecięce, Wydawnictwo Poznańskie, Poznań 1972.

Iwaszkiewicz Jarosław, Spotkania z Szymanowskim, Polskie Wydawnictwo Muzyczne, Kraków 1981.

Jacobson Roman, Poetyka w świetle językoznawstwa, w: W poszukiwaniu istoty jezyka. Wybór pism, wybór, red. nauk. i wstęp Maria Renata Mayenowa, t. 2, Państwowy Instytut Wydawniczy, Warszawa 1989, s. 113.

Kwiatkowski Jerzy, Dwudziestolecie międzywojenne, Wydawnictwo Naukowe PWN, Warszawa 2002.

Pawelec Dariusz, Od kotyski do trenu. $Z$ hermeneutyki form poetyckich, Wydawnictwo Uniwersytetu Śląskiego, Katowice 2006.

Podhorska-Okołów Stefania, $Z$ tajników poetyckiego rzemiosła. J.K. Iłłakowicz o swojej twórczości, „Wiadomości Literackie” 1925, nr 9, s. 2.

Patrycja Rosół

\section{Konteksty muzyczne w Rymach dziecięcych Kazimiery Iłłakowiczówny}

\author{
Streszczenie
}

Szkic poświęcony jest Rymom dziecięcym Kazimiery Iłłakowiczówny - tomikowi miniatur poetyckich przeznaczonych dla dzieci, do których Karol Szymanowski skomponował cykl pieśni na głos i fortepian pt. Rymy dziecięce op. 49 zadedykowanych zmarłej siostrzenicy - Pamięci Alusi. Autorka szkicu przywołuje okoliczności napisania cyklu oraz wspomina o konflikcie, jaki powstał między poetką a kompozytorem, który bez zgody autorki wydał pieśni w wydawnictwie Universal-Edition. 
W dalszej części szkicu Autorka skupia uwagę na intersemiotycznej analizie muzycznego przekładu wierszy (zabiegi dynamiczne, rytmiczne, agogiczne oraz melodyczne), w którym przejawia się kompozytorski zamysł ilustrowania tekstu dźwiękami.

Słowa kluczowe: Karol Szymanowski, Kazimiera Iłłakowiczówna, Rymy dziecięce, poezja, muzyczność

\title{
Musical contexts in Kazimiera Iłłakowiczówna's Children's Rhymes
}

\author{
Summary
}

The topic of this paper is Kazimiera Iłłakowiczówna Children's Rhymes - a book of poetic miniatures for children, to which Karol Szymanowski composed a set of songs for voice and piano entitled Children's Rhymes Op. 49 in memory of his late niece Alusia. The author of this paper discusses the circumstances of the work's composition and recalls the conflict between the poetess and the composer that arose when he got the songs published by the Universal-Edition publishing house without her permission. Next, the autor focuses on an intersemiotic analysis of the musical interpretation of the poems (dynamic, rythmical, agogic and melodic modifications), based on the conception of illustrating text with the use of sounds.

Keywords: Karol Szymanowski, Kazimiera Iłłakowiczówna, Children’s Rhymes, Poetry, Musicality

Mgr Patrycja Rosół - doktorantka studiów III stopnia na Uniwersytecie Opolskim, absolwentka filologii polskiej Uniwersytetu Śląskiego w Katowicach. Ukończyła Diecezjalną Szkołę Organistowską II stopnia w Gliwicach w klasie organów. Jako muzyk spełnia swoje pasje, będąc organistką w parafii. Ukończyła także studia z zakresu logopedii. Prowadzi terapię behawioralną i zajęcia umuzykalniające z dziećmi o spektrum autyzmu. 